\title{
PRINCIPLES BEHIND THE NEW REVISED EDITION OF BRÜNNOW AND FISCHER'S ARABISCHE CHRESTOMATHIE: A TRIBUTE TO THE SCHOLARLY METHODS OF MICHAEL G. CARTER ${ }^{1}$
}

\author{
Lutz Edzard
}

\section{UNIVERSITY OF OSLO}

This paper examines the editorial principles underlying the eighth revised edition of Rudolf-Ernst Brünnow's and August Fischer's Arabische Chrestomathie aus Prosaschriftstellern, as carried out by Lutz Edzard and Amund Bjørsnøs. An essential feature of the added commentary to the text excerpts is the recourse to the methods and terminology in native Arabic grammatical theory. Throughout his career in research and teaching, Michael G. Carter has placed much weight on the appropriate application of native Arabic scholarship to an apt description and analysis of both Classical and Modern Standard Arabic, a principle also adopted in this new, eighth edition.

\section{Introduction}

One of the major achievements of Michael G. Carter has been to demonstrate the unbroken relevance of native Arabic grammatical theory to the proper description of morphological and syntactical features in both Classical and Modern Standard Arabic. Often, the unreflected use of Latinate terminology is not helpful when it comes to the analysis of the idiosyncrasies of Arabic grammar, or rather features that are not entirely in line with related features in Latin and Greek grammar. Concepts developed in native Arabic grammatical theory need not completely replace the explanatory devices of Latin and Greek grammar; however, additional recourse to the native Arabic concepts is definitely conducive to a better understanding of Arabic grammar. As will be shown in this paper, case and mood in Arabic provide major examples in this context. It is, of course, a truism that Arabic syntax, even on an elementary level, can hardly be described without terms such as damīr a $a \check{s}-\check{s} a^{\circ} n$ (for a

${ }^{1}$ This paper is dedicated to Michael G. Carter on the occasion of his 70th birthday in 2009. It is a fortunate coincidence that Michael Carter in fact checked the grammar, style, and contextual relevance of the notes to the English version of the revised edition of Rudolf-Ernst Brünnow's and August Fischer's Chrestomathie, for which we are most grateful. 
pronoun of circumstance) or the $h \bar{a} l$-clause (for circumstantial qualifier). On a more advanced level, terms such as mașdar mimmi (a noun with an $m$-prefix, functioning as a mașdar) or ${ }^{\circ}$ in al-muhaffafa ( ${ }^{\circ}$ in + independent case, followed by la-, instead of 'inna + dependent case; cf. Wright, vol. 2: 81), to adduce only two examples, are indispensable for sound grammatical education. Moreover, concepts in native Arabic grammatical theory often exhibit striking parallels to concepts developed independently in modern linguistic theory, another point in favour of maintaining such terminology, as Michael G. Carter has frequently argued. ${ }^{2}$ The following discussion is not intended to bear directly on the perennial question of the extent to which Arabic grammatical theory may or may not be dependent on Greek grammatical theory. ${ }^{3}$ This is an issue which is independent of the question as to whether or not Greek (or Latin) terms, such as diptote/triptote, are infelicitous as far as precise synchronic description of a morpho-phonological phenomenon in Arabic is concerned.

The new edition of Brünnow and Fischer's Chrestomathie presented an opportunity to apply these principles, i.e., to refer to native Arabic concepts in addition to the reference to traditional grammatical tools, such as William Wright's and Wolfdietrich Fischer's grammars of Classical Arabic. This proved to be all the more important, insofar as the chrestomathy ended and culminated with the complete text of Ibn ${ }^{\circ} \bar{A}$ ğurrūm's Kitāb al- ${ }^{\circ} \bar{A}$ ğurrūmìya. Carter has dealt with this text in his detailed analysis of aš-Širbīn̄̄'s treatise, Nür as-sağìya fì hall 'alfăz al${ }^{\circ} \bar{A}$ ğurrümìya, which technically constitutes a sort of hypertext flowing around Ibn 'A Ăgurrūm's treatise. The editors also decided to add the following text excerpts to the previous canon of texts, in line with a suggestion to that effect by August Fischer in his preface to the fourth edition of the chrestomathy from 1928 :

(i) two excerpts of the preface to al-Halīl's Kitāb al- ${ }^{c}$ ayn (1: 47-49 and 58-60), which illustrate the phonetic principles and the root combinatorics, respectively, underlying this first Arabic dictionary.

(ii) the lemma 'quțrub' in Ibn Manẓūr's Lisān al-'arab and azZabīdī's Tāğ al- ${ }^{c}$ arūs.

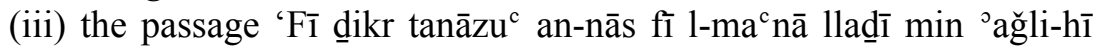
summiya l-yaman yamanan wa-l- 'irāq wa-š-šām wa-l-ḥiğāz' in al-

\footnotetext{
${ }^{2}$ Cf. his seminal paper from 1973, in which the functional reduction of syntax to binary units, as perfomed by Sībawayhi, is compared with the principles in Immediate Constituent Analysis.

${ }^{3}$ For a concise discussion of the arguments in this connection cf. Carter 1997.
} 


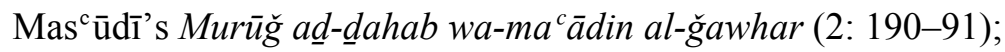

(iv) the passages 'Fī ğumal min 'ahbār al-buldān' and 'Bağdād' in Yāqūt's Mu' čăam al-buldān (1: 52-54 and 677-678).

The 'geographical' excerpts at the end of the chrestomathy are etymological and lexical in nature and thus in harmony with the preceding passages. And again, the insight gained by Carter into various grammatical and lexical features of these texts proved to be extremely useful for the presentation of the new edition. ${ }^{4}$

\section{Examples}

In the following, we shall investigate relevant examples in context. ${ }^{5}$ First, the issue at hand is explained and the relevance of native grammatical theory in the respective context highlighted. Then the Arabic excerpt under discussion is cited, accompanied by a translation and followed verbatim by the commentary in the English version of the revised chrestomathy.

2.1 The first example involves the different grammatical uses of the case endings. As is well known, the Arabic term $r a f^{c}$ covers the functions of the $u$-ending as marker of both 'nominative' (case) and 'indicative' (mood), just as the Arabic term nașb covers the functions of both 'accusative' (case) and 'subjunctive' (mood). However, not all instances of $a$-endings on Arabic nouns can be appropriately captured by the term 'accusative', which has only a few uses other than marking the direct object. Therefore, it makes sense to use the terms 'independent case' for the 'nominative' and 'dependent case' for the 'accusative', respectively. The following example concerns the apposition after a pronoun in the first or second person (p. 4, 1. 2-5):

$$
\begin{aligned}
& \text { (1) }
\end{aligned}
$$

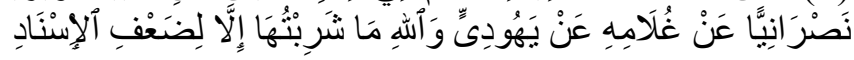

'We, the hadīt experts, argue like Sufyān ibn ${ }^{c}$ Uyayna and Yazīd ibn Hārūn. "Are we supposed to believe a Christian based on [the testimony of] his servant based on [the testimony of] a Jew? By God, I only drank the wine because of the weakness of the 'isna $\bar{a}$."

1.2 نَحْنُ أَصْحَابَ ألْحَدِيثِ : apposition after a pronoun in the first or second person in the dependent case (nașb in native Arab terminology);

\footnotetext{
${ }^{4} \mathrm{Cf}$. the cogent summaries of these topics in Carter 1990a and 1990b.

${ }^{5}$ Page and line numbers in parentheses refer to the Arabic section of the chrestomathy.
} 
cf. Fischer $\S \S 383 \mathrm{~b}$ and 393 , note 2 ; the term 'accusative' does not fit here, just as it does not in the cases of the absolute negation, نَحْنُ أَصْحَابَ ألْحَدِيث vocative in the $i d \bar{a} f a$, predicative participle ( $h \bar{a} \bar{a} l$ ), predicate of kāna and its sisters, and vocalised subject after ${ }^{\circ}$ inna (cf., for example, Lipiński 2001: 259-67); rather, we are looking at a trace of an old Afroasiatic 'predicative' case, associated with an $a$-ending; for quasicompounds like șăhib $x$, ${ }^{\circ} a h l x$, or $\underline{d} \bar{u} x$ (cf. Fischer, § 391 and Wright vol. $2, \S 81)$.

2.2 At this point, it is instructive to consult the text of the ${ }^{\circ} \bar{A} \check{g} u r r \bar{u} m \bar{y} y a$ itself. One sees at once that the strictly functional definition of ${ }^{\circ} i c r a b$ captures the distribution of the 'case'-marking vowels better than the mere transfer of the terms 'nominative', 'genitive', and 'accusative' to the description of the different grammatical operations in question. The ${ }^{\circ} \bar{A}$ ğurrümìya defines the term ${ }^{\circ} i{ }^{c} r a \bar{b} b$ as follows (p. 171, 1. 11-12):

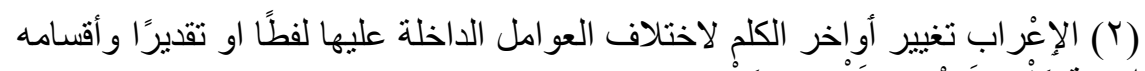

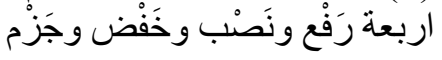

'Inflection [properly 'Arabi(ci)sation', i.e., the insertion of vowels] is the change of word-endings due to the variation of operators, which occur before them, either explicitly or implicitly. Its subdivisions are four: independence, dependence, obliqueness, and apocopation' (cf. Carter 1981: $34,38)$.

1. الإعُراب 11 : cf., for instance, the articles 'Declension' (L. Edzard) and ' 'I rāb' (K. Dévényi), in: EALL, vols. 1 and 2, respectively, s.v., for the functional character of the Arabic case and mood endings; note especially that the term $r a f^{c}$ 'independence' (literally: 'raising') covers both the 'nominative' case and the 'indicative' mood (i.e., a grammatical $u$-ending), and the term nașb 'dependence' both the 'accusative' case (in its various functions) and the 'subjunctive' mood (i.e., in both cases a grammatical $a$-ending).

1. 12 نقدير 'implicitly' ('by estimation'), i.e., beneath the surface structure; cf. Carter 1981: 35; cf. also the lemma 'Takdīr' in $E I^{2}$ (A. Levin).

2.3 As far as the $a$-ending is concerned, the ${ }^{\circ} \bar{A}$ grurrummiya lists the following possible functions of nassb, of which the direct object is just one possibility among many others (p. 179, 1. 1-5):

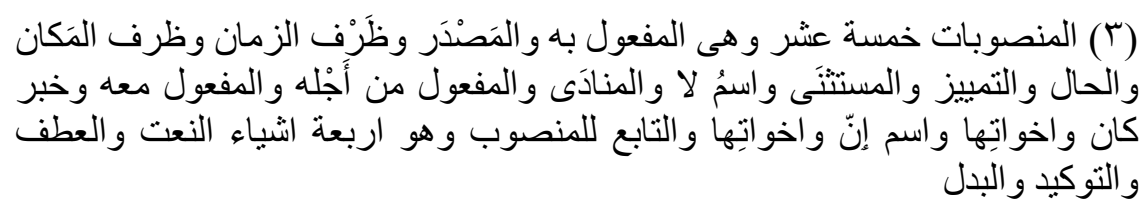


'The dependent forms are fifteen in number: and they are the direct object, the verbal noun, the time-qualifier, the space-qualifier, the circumstantial qualifier, the specifying element, the excepted element, the noun negated by $l \bar{a}$ 'no', the vocative, the object of reason, the object of accompaniment, the predicate of kanna 'to be' and its related verbs, the subject-noun of 'inna 'verily' and its related particles, the two objects of zanantu 'I thought' and its related verbs\}, and the concordant of a dependent element, which comprises four things: the adjective, the coordinated element, the corroborative, and the substitute' (cf. Carter 1981: $324,326,328)$.

1.1 the following enumeration only contains fourteen examples: therefore, the Beirut edition interpolated مفعو لا ظنتن و اسم إنّ the two objects of zanantu and it sisters' between و وأخواتها as fifteenth example; cf. Trumpp 1876: 86 and Carter 1981: 326f.; the older editions of the chrestomathy suggest that the fifteenth example may have been the $m \bar{a}$ al-hiğazzìya, as was taught by the commentator of the ${ }^{\circ} \bar{A} \grave{g} u r r u \bar{m} \bar{y} y a$, al-Mākūdì (d. 1401).

2.4 A famous problem in the history of Arabic grammar relating to the opposition between independent case $\left(r a f^{c}\right)$ and dependent case (nașb) is the construction known as mas alat az-zunbūr or al-mas ala alzunbürīya (cf. Blau 1963, Talmon 1997, and Carter 2004: 13). The issue here is whether or not the predicate of huwa in the following quotation can stand in the dependent case (i.e., can be preceded by the 'accusative' marker ${ }^{\wedge} \bar{l} y \bar{a}-$-) or not. According to Sỉbawayhi, this was not the case, whereas his adversary al-Kis $\bar{a}^{\top} \overline{1}$ claimed the contrary and bribed a Bedouin to testify to that effect. Consider the following quotation from Ibn Hallikān's Wafāyāt al- ${ }^{\circ} a^{c} y \bar{a} n$ (p. 100, 1. 8-10):

( ) وزعم الكسائى ان العرب تقول كنت اظن الزنبور اثد لسعامن النحلة فاذا هو اياها

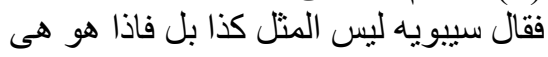

"Al-Kisā ${ }^{\top} \overline{1}$ claimed that the Bedouin would say, "I have always thought that the hornet was more painful in stinging than the bee, and lo and behold, it is just that! (fa- $\left.{ }^{\circ} i \underline{d} \bar{a} h u w a{ }^{\circ} \bar{\imath} y \bar{a}-h \bar{a}\right)$." Sībawayhi, however, said: "The example is not [grammatically correct] like that; rather [the correct version is]: 'and lo and behold, it is that! (fa- ${ }^{\circ}$ id a huwa hiya)."'

1. 10 فاذا هو اياها - فاذا هو هى : 'lo and behold, it is that!'; cf. Fischer $\S \S 280$ and 444 as well as Wright vol. 2: 329; cf. also Ibn al- ${ }^{\circ}$ Anbārī's

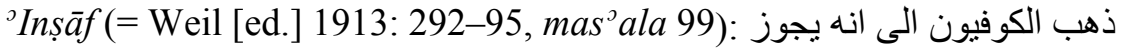
ان يقال كنت اظنّ ان العقاب اشدّ لسعة من الزنبور فاذا هو اباها وذهب البصريون الى 
انه لا يجوز ان يقال فاذا هو اياها ويجب ان يقال فاذا هو هى for an in-depth analysis of the so-called mas ${ }^{\circ}$ ala zunbūrìya, cf. Blau 1963.

2.5 So far we have looked at the syntactical implications of the terms $r a f^{c}$ 'independent case' and nas b 'dependent case'. But native Arabic is also important for a proper description of the pure morphology of case marking in Arabic. Michael Carter (personal communication) has always been dissatisfied with the unreflected use of the Greek terms 'diptote' ('surfacing in two cases') and 'triptote' ('surfacing in three cases'), especially as all diptotes become triptotes when annexed or prefixed with the definite article. Therefore, Carter prefers the terms 'semi-declinable' and 'fully declinable' in this context. The following quotation from the ${ }^{\circ} \bar{A} \breve{g} u r r \bar{m} \bar{\imath} y a$ is instructive (p. 173, 1. 2-8):

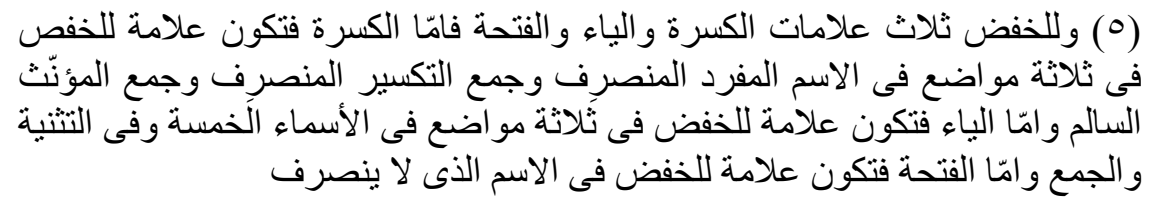

'Obliqueness has three markers, (1) $i$, (2) $\bar{\imath} / a y$, and (3) $a$. $i$ is the marker of obliqueness in three places: (1) in the fully declinable singular noun, (2) in the fully declinable broken plural, and (3) in the sound feminine plural. And $\bar{i} /$ ay is the marker of obliqueness in three places: (1) in the five nouns [i.e. nouns tertiae infirmae, e.g., $\left.{ }^{\circ} a b \bar{i}\right],(2)$ in the dual, and (3) in the [sound] plural. And $a$ is the marker of obliqueness in the semideclinable noun' (cf. Carter 1981: 72, 74).

1. 2 Carter (1981: 73) suggests the translation 'obliqueness' (literally: 'lowering').

1. 4 منصرِ : 'fully declinable', i.e., 'triptote'.

1.8 لا ينصرف: which is not munșarif, (but only) 'semi-declinable', i.e., 'diptote'.

2.6 The use of Arabic terminology is also sensible in the case of other constructions, e.g., as regards the specific function of the preposition $\mathrm{min}$ in the 'empty' comparison in the construction known as mas'alat al-kuhl. ('Satzvergleich'). Consider the following excerpt from the sirra nabawiya (p. 62, 1. 8-10):

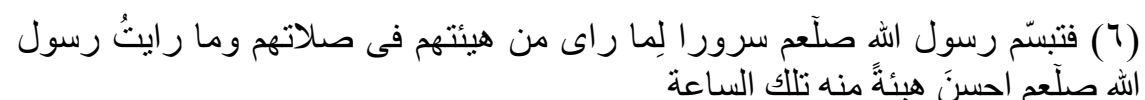


'The Apostle smiled with joy when he marked their mien in prayer, and I never saw him with a nobler expression than he had that day' (cf. Guillaume 1955: 681).

1.10 منه : o refers to Muhammad; the construction is known as mas alat al-kuḥl; cf. $E I^{2}$, s.v. 'Tafụīl' (M. Carter).

2.7 A further construction, which can only be understood in its Arabic and Semitic context, is the conditional clause in which the apodosis does not express a direct logical consequence of the protasis, but rather expresses a comparison with a previous event (the logical apodosis has to be added mentally). In German grammatical nomenclature, the phenomenon is known as 'Bedingungssatz mit Verschiebung'. Again, the sira nabawiya features a relevant example (p. 62, 1. 16-p. 63, 1. 4):

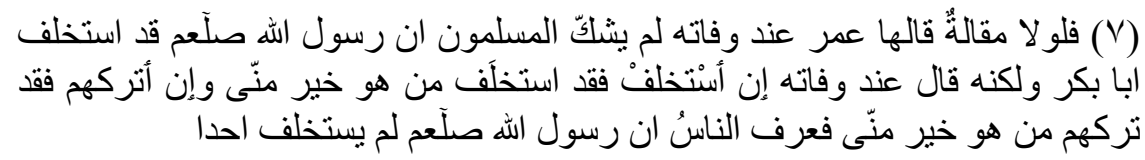

'Had it not been for what ${ }^{c}$ Umar said when he died, the Muslims would not have doubted that the Apostle had appointed ${ }^{\circ} \mathrm{Abu}$ Bakr his successor; but he [ $\left.{ }^{\mathrm{C}} \mathrm{Umar}\right]$ said when he died: "If I appoint a successor one who is better than I did so; and if I leave them [to elect my successor] one better than I did so." So the people knew that the Apostle had not appointed a successor and "Umar was not suspected of hostility towards 'Abū Bakr' (cf. Guillaume 1955: 681).

11. 1-3: one can only try to infer the meaning of this conditional passage ('Bedingungssatz mit Verschiebung'; cf. Fischer $\S 449$, where the locus classicus of this construction, Q 12: 77, is quoted) from the hadīt literature, e.g., Buhārī, Șahịh, 'Aḥkām, Bāb 51, who states that 'Umar is the speaker of the passage; هن هو خبر منّى functions in both instances as subject (referring to Muhammad): ' in 'astahlif fa-qadi stahlafa man huwa hayrun minn-ī wa- ${ }^{\supset}$ in ${ }^{\circ}$ atruk-hum fa-qad taraka-hum man huwa hayrun minn-ī; for the involved consecutio temporum, cf. also Fischer $\S 450$.

2.8 Michael Carter has cogently contributed to the now commonly accepted position that the historical value of Arabic phonemes cannot automatically be equated with their modern counterparts (cf. Carter 2004: 120-31). As stated above, the newly added sections in the chrestomathy contain two excerpts from al-Halīl's Kitāb al- ${ }^{c} a y n$, the first of which also has a bearing on this issue in that it concerns the phonetic principles underlying the Halīilian sequence. Let us here consider a passage from the second excerpt, which concerns the possible number of permutations, 
depending on the number of root consonants. (The issue of co-occurrence restrictions is not raised explicitly in this context.) Here is the quotation (p. 186, 1. 8-p. 187, 1.6):

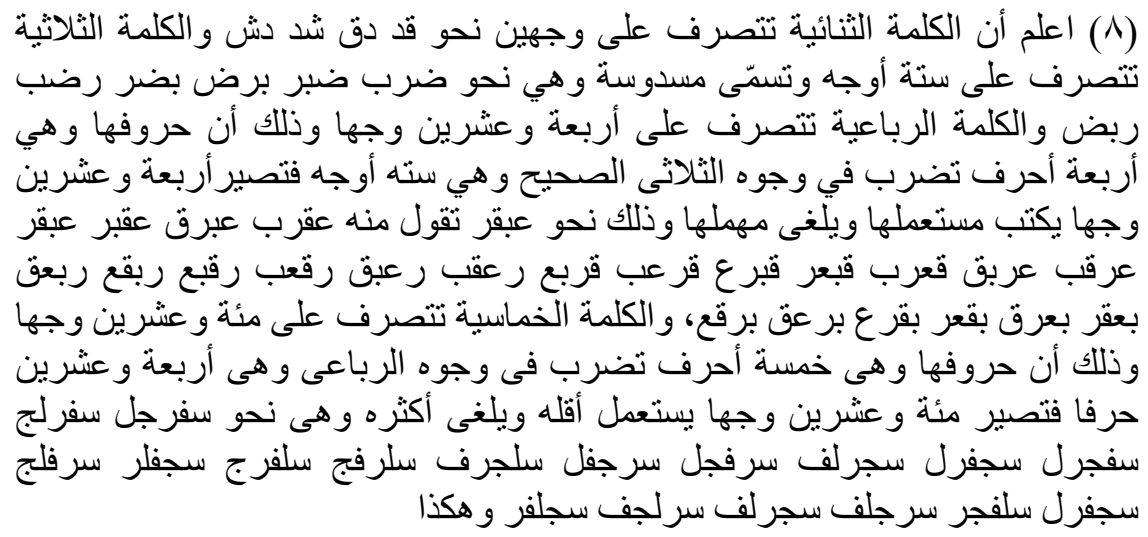

'Know that the biliteral doubled word runs in two permutations, as radda and darra, šadda, and dašša. The triliteral has six permutations and is called "sixfold", e.g., daraba, dabara, barada, badara, radaba, and rabada. The quadriliteral has twenty-four forms, because it has four letters, which are multiplied by the six forms of the triliteral, making twenty-four - of which those in use are recorded [in this work] and those neglected are omitted. An example is 'cabqara, from which one can form 'aqraba, 'abraqa, 'aqbara, 'abqara, 'arqaba, 'arbaqa, qa'craba, qab cara, qabrac $a, q a r^{c} a b a, q a r b a^{c} a, r a^{c} q a b a, r a^{c} b a q a, r a q^{c} a b a, r a q b a^{c} a, r a b q a^{c} a$, $r a b^{c} a q a, b a^{c} q a r a, b a^{c}$ raqa, baq ara, baqrac $a, b a r^{c} a q a$, and barqa $a^{c} a .^{6}$ The quinquiliteral word produces 120 permutations, because the number of its five letters is multiplied by the twenty-four quadriliteral forms, making 120, of which only a minority are in use, the majority being rejected. An example is safarğal ['quince'], safarlağ, safağral, sağafral, sağarlaf, saraf̌̆al, sarağfal, sală̆raf, salarfağ, salafrağ, sağaflar, sarağlaj, sağafral, salafğar, sarağlaf, sağarlaf, saralğaf, sağalfar, and so on'7 (cf. Haywood 1960: 36).

1.10 مسدوسة : 'sixfold'; generally speaking, a root containing $\mathrm{n}$ radicals can surface in $n$ ! permutations ('factorial n' $=\mathrm{n} \times[\mathrm{n}-1] \times \ldots \times 1$ ), i.e., a root with two radicals in two permutations $(2 \times 1)$, a root with three radicals in six permutations $(3 \times 2 \times 1)$, a root with four radicals in twenty-four permutation $(4 \times 3 \times 2 \times 1)$, and a root with five radicals

6 The form qac bara is missing in the Arabic list.

7 The form sağarlaf occurs twice in the Arabic list. 
in one hundred and twenty permutations $(5 \times 4 \times 3 \times 2 \times 1)$; only few sets of roots exhaust the possibilities. ${ }^{8}$

2.9 Other addenda in the chrestomathy are the lexical entries "qutrub" in the Lisān $a{ }^{-}{ }^{c} a r a b$ and the Tăg al- ${ }^{c} a r \bar{u} s$. Interestingly, qutrub, deriving from the Greek $\lambda v \kappa o ́ v \theta \rho \omega \pi \mathrm{s} \varsigma$ 'werewolf' (via Syriac qantrōpos) and a term for various psychological diseases, was also the nickname of a grammarian who used to creep around Sībawayhi's door in the early morning. As far as we know, Quțrub ( ${ }^{\circ} \mathrm{Abu}{ }^{\mathrm{c}}$ Alī Muhammad ibn alMustanī $)^{9}$ claimed that vowels were no longer case markers at his time, but merely sandhi vowels facilitating pronunciation and serving to distinguish context forms from pausal forms (cf. Carter 2004: 138) ${ }^{10}$ Here are two passages from the lemma "qutrub" (p. 188, 1. 1-2, and p. 189, 1. 3-5):

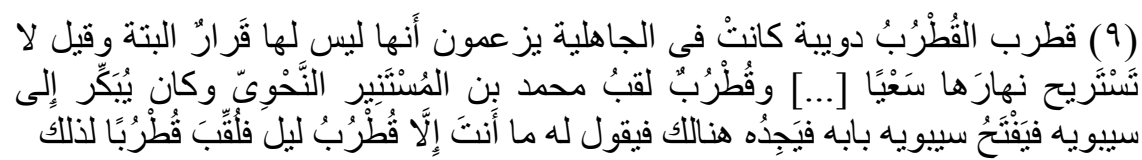

'Qutrub: The qutrub is a little reptile from the Ğāhilīya. One claims that it never keeps quiet, and it is said that it never rests, constantly walking around. [...] And qutrub is also the nickname of Muhammad ibn alMustanīr, the grammarian, who used to visit Síbawayhi early in the morning, and when Sībawayhi opened his door and found him there, Sỉbawayhi said to him: "You are just a night-qutrub." Therefore, Muhammad ibn al-Mustanīr got the nickname Qutrub.'

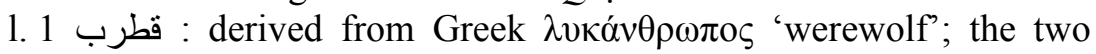
lexical entries in Lisān al- ${ }^{c}$ Arab by Ibn Manzūur (d. 1312) and in Tāğ al${ }^{c} A r u \bar{s}$ by az-Zabīdī (d. 1791) should be studied in close conjunction with Ullmann 1976: دويبة : دو ئل

1.3 محمد بن المُسْتَنَيْر : grammarian, d. 821.

1.4 كان يُبَكَ大ِ 4 : 'he used to visit in the morning'.

2.10 The last addendum in the chrestomathy are two excerpts from Yaqūt's geographical lexicon $M u^{c}$ ğam al-buldān. Let us finish our survey of the new edition with two passages in the section about the city Baghdad, in which different etymological approaches to the place name Bagd $\bar{a} d$ are pondered (p. 198, 1. 4-7, and p. 200, 1. 4-5):

\footnotetext{
${ }^{8}$ Based on a root count in Wehr, approximately every seventh possible root is attested among the triliteral roots.

${ }^{9}$ Died in 206/821. Cf. GAS 8: 61-67; 9: 64-65.

10 This observation is definitely in line with what we assume to know about diglossia/polyglossia and the loss of ${ }^{\circ} i^{c} r \bar{a} b$ in the history of Arabic.
} 


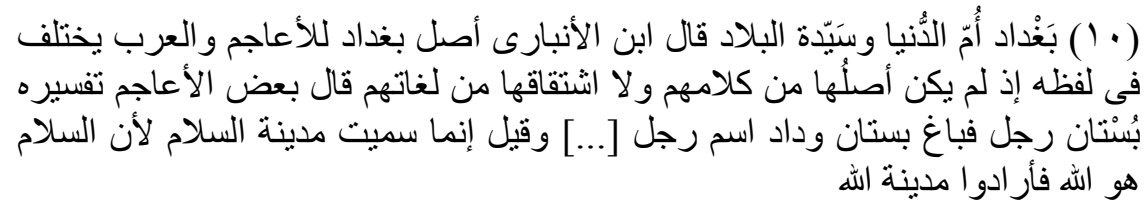

'Baghdad is the mother of the world and the mistress of countries. Ibn al'Anbārī said: "The origin of [the word] Bagdād is with the Persians, and the Arabs differ on its pronunciation, since the origin of Bag $d \bar{a} d$ does not belong to their speech and its etymology does not lie within their language." Some Persians said that its [correct] interpretation is 'garden of a man', $b \bar{a} \dot{g}$ being 'garden' and $d \bar{a} d$ the name of a man. [...] It was also said that Bagdād was called 'city of peace', because peace means God. Thus they meant "city of God."”

1. بَغْداد 4 : modern Iranists derive the name Baghdad from Old Persian bag 'god' and $d \bar{a} d$ 'given', i.e., 'given by God' (cf. H. Kennedy, 'Baghdad', Encyclopcedia Iranica, vol. 3 (1989): 412-15); however, the name is already attested during the reign of Hammurapi in cuneiform documents, the ultimate etymology remaining unclear (cf. $E I^{2}$, s.v. 'Baghdād').

\section{Conclusion}

With this short overview we hope to have shown the principles underlying the new edition of Brünnow and Fischer's Chrestomathie and to have given tribute to Michael Carter, both as regards his methodological principles in general and his particular input to the formulation of the newly added notes to the chrestomathy in particular. It is hoped that the rather difficult text excerpts thus become more accessible to beginning students of Classical Arabic and that students at the same time gain some understanding of the continuing relevance of native Arabic grammatical theory.

\section{REFERENCES}

\section{Primary sources}

al-Buhārī, Kitāb al-ğāmic aș-ṣaḥịh = Recueil des traditions mahométanes par Abou Abdallah Mohammed ibn Ismaîl el-Bokhâri. Ed. M. Ludolf Krehl (vols. 1-3) and Th. W. Juynboll (vol. 4). Leiden: E. J. Brill, 1862-1908.

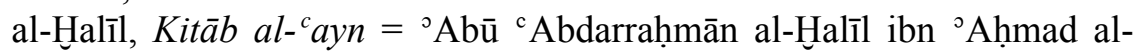
Farāhīdī. Kitāb al- ${ }^{c} a y n$. Ed. Mahdī al-Mahzzūmī and ${ }^{\top} \mathrm{Ibrāhīm}$ asSāmarrā̄̄ō. 8 vols. Baghdad: Dār ar-Rašīd li-n-Našr. 1980. 
Ibn al- ${ }^{\circ}$ Anbārī, Kitāb al- ${ }^{\supset}$ inșā f fì mas $\bar{a}^{\supset} i l$ al-hilā $f=$ Weil, Gotthold (ed.). Kamāl ad-Dīn ${ }^{\circ} \mathrm{Ab} \overline{1}$ 1-Barakāt ${ }^{\mathrm{C}} \mathrm{Abd}$ ar-Rahmān ibn ${ }^{\circ} \mathrm{Ab} \overline{1}$ Sacīd al-

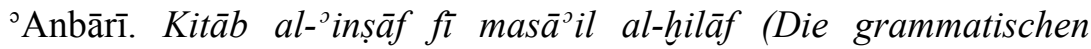
Streitfragen der Basrer und Kufer). Leiden: E. J. Brill, 1913.

Ibn Hallikān, Kitāb wafayāt al- ${ }^{\circ} a^{c} y \bar{a} n=$ Wafāyāt al- ${ }^{\circ} a^{c} y \bar{a} n$ wa- ${ }^{\circ} a n b \bar{a}^{\supset}$ `abnā̄ az-zamān, ed. 'Tḥsān ' Abbās. 8 vols. Beirut: Dār Șādir, 196877.

Ibn 'Ishāq, Kitāb sīrat an-nabī = Wüstenfeld, Ferdinand. Das Leben Muhammed's nach Muhammed Ibn Ishâk bearbeitet von Abd el-Malik Ibn Hischâm. 2 vols. Göttingen: Dieterichsche Universitätsbuchhandlung.

Ibn Manẓūr, Lisān al- ${ }^{c} a r a b=$ Muhammad ibn Mukarram Ibn Manẓūr. Lisān al- ${ }^{c}$ arab. Beirut: Dār ' Ihya $\bar{a}^{\supset}$ at-Turāt al- ${ }^{\mathrm{C}}$ Arabīi, 1988.

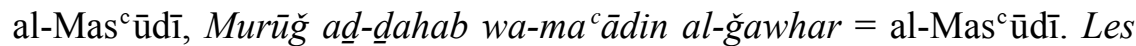
Prairies d'or (Murūğ ad-dahab wa-mac ādin al-ğawhar). Edition Barbier de Meynard et Pavet de Courteille revue et corrigée par Charles Pellat. 7 vols. Beirut: Publications de l'Université Libanaise, 1966-79.

Yāqūt, Mu'ğam al-buldān= Jacut's geographisches Wörterbuch aus den Handschriften zu Berlin, St. Petersburg und Paris, herausgegeben von Ferdinand Wüstenfeld. 6 vols. Leipzig: Brockhaus, 1866-73.

az-Zabīīin, Tāğ al- ${ }^{c}$ arūs = Muhammad Murtaḍā az-Zabīdī. Tāğ al- ${ }^{c}$ arūs min ğawāhir al-Qāmūs. Kuwait: Maṭba ${ }^{c}$ at Hukūmat al-Kuwayt, 1965.

\section{Secondary sources}

Blau, Joshua. 1963. 'The Role of the Bedouins as Arbiters in Linguistic Questions and the Mas ala az-zunbūriyya'. Journal of Semitic Studies 8: 42-51.

Brünnow, Rudolf-Ernst. 1895. Chrestomathie aus arabischen Prosaschriftstellern im Anschlus an Socin's Arabische Grammatik. Berlin: Verlag von Reuther und Reichard.

Brünnow, Rudolf-Ernst, and August Fischer. (1911-)1913 (2nd ed.). Chrestomathie aus arabischen Prosaschriftstellern im Anschlu $\beta$ an Socin's arabische Grammatik. Berlin: Verlag von Reuther und Reichard.

1988 (7th ed.). Arabische Chrestomathie aus Prosaschriftstellern. Wiesbaden: Harrassowitz.

. 2008a (8th ed.). Klassisch-arabische Chrestomathie aus Prosaschriftstellern. 8., neu bearbeitete Auflage von Lutz Edzard und Amund Bjørsnøs. Wiesbaden: Harrassowitz. 
2008b (8th ed.). Chrestomathy of Classical Arabic Prose Literature. 8th, revised edition by Lutz Edzard and Amund Bjørsnøs. Wiesbaden: Harrassowitz.

Carter, Michael G. 1973. 'An Arab Grammarian of the Eighth Century A.D.: A Contribution to the History of Linguistics'. Journal of the American Oriental Society 93/2: 146-57.

- 1981. Arab Linguistics: An Introductory Classical Text with Translation and Notes. Amsterdam: J. Benjamins.

1990a. 'Arabic grammar'. In M. J. L. Young et al. (eds.), Cambridge History of Arabic Literature: Religion, Learning and Science in the ${ }^{c}$ Abbasid Period, 118-38 (Cambridge: Cambridge University Press).

. 1990b. 'Arabic Lexicography'. In M. J. L. Young et al. (eds.), Cambridge History of Arabic Literature: Religion, Learning and Science in the 'Abbasid Period, 106-17 (Cambridge: Cambridge University Press).

- 1997. 'Sībawayhi' in Encyclopaedia of Islam, 2nd edition (Leiden: E. J. Brill). 2004. Sïbawayhi. London: Tauris.

Edzard, Lutz. 2001. 'Grammatical Systems in Indigenous and in Foreign Perspective: The Case of Arabic'. In Hannes Kniffka (ed.), Indigenous Grammars across Cultures, 317-45 (Frankfurt a.M.: Peter Lang).

Fischer, August. 1940. 'Allerlei Bemerkungen zu meiner 'Arabischen Chrestomathie". Zeitschrift der Deutschen Morgenländischen Gesellschaft 94: 313-31.

Fischer, Wolfdietrich. 2006 (4th ed.). Grammatik des Klassischen Arabisch. Wiesbaden: Harrassowitz.

Guillaume, Alfred. 1955. The Life of Muhammad: A Translation of Ishāa's Sìrat Rasūl Allāh. London; New York: Oxford University Press.

Haywood, John. 1960. Arabic Lexicography: Its History and its Place in the General History of Lexicography. Leiden: E. J. Brill.

Ibn Khallikan's Biographical Dictionary. Translated from the Arabic by Bn. Mac Guckin de Slane. 1842-71. 4 vols. New York \& London: Johnson Reprint Corporation, [1961].

Isaksson, Bo. 2007 (3rd ed.). Hind behärskade högspråket ...: Textkurs $i$ klassisk arabiska med utgångspunkt $i$ R.-E. Brünnows och A. Fischers Arabische Chrestomathie. Uppsala: Uppsala Universitet.

Jwaideh, Wadie. 1959. The Introductory Chapters of Yāqūt's Mucjam alBuldān. Translated and annotated. Leiden: E. J. Brill. 
Lipiński, Edward. 2001. Semitic Languages: Outline of a Comparative Grammar. Sterling, Va.: Peeters.

Mas ${ }^{\mathrm{C}} \mathrm{u} d \bar{i}$ (mort en 345/956). Les Prairies d'or. Traduction française de Barbier de Meynard et Pavet de Courteille revue et corrigée par Charles Pellat. 3 vols. Paris: Société Asiatique, 1962-71.

Rodgers, Jonathan. 2002 (3rd ed.). A Grammar of Classical Arabic (English translation of Wolfdietrich Fischer's Grammatik des Klassischen Arabisch). New Haven: Yale University Press.

Sasse, Hans-Jürgen. 1984. 'Case in Cushitic, Semitic and Berber'. In J. Bynon (ed.). Current Progress in Afro-Asiatic Linguistics, 111-26. Amsterdam/Philadelphia: J. Benjamins.

Talmon, Rafael. 1997. Arabic Grammar in its Formative Age: Kitāb al${ }^{\mathrm{c}}$ Ayn and its Attribution to Halīl b. Ahmad. Leiden: Brill.

Trumpp, Ernst. 1876. Einleitung in das Studium der arabischen Grammatiker: Die Ajrūmiyyah (sic!) des Muhammad bin Daūd. Munich: Verlag der K. Akademie.

Ullmann, Manfred. 1976. 'Der Werwolf. Ein griechisches Sagenmotiv in arabischer Verkleidung'. Wiener Zeitschrift für die Kunde des Morgenlandes 68: 171-84.

Wright, William. 1896-98 (3rd ed. 1967). A Grammar of the Arabic Language. Translated from the German of Caspari, rev. W. Robertson Smith and M. J. de Goeje. 2 vols. Cambridge: Cambridge University Press.

Zetterstéen, K.V. 1919. 'Review of R. Brünnow's Arabische Chrestomathie aus Prosaschriftstellern in zweiter Auflage völlig neu bearbeitet und hrsg. von August Fischer: Porta Linguarum Orientalium XVI. Berlin, Reuther \& Reichard, 1911-1913 ...'. Le Monde Oriental 13: $137-38$. 